\title{
Molitva šutnje, govora i kulta kao načini izvršenja religije u filozofiji Bernharda Weltea
}

\author{
Prikaz temeljnih aspekata
}

\author{
SUZANA MASLAĆ* \\ • https://doi.org/10.31823/d.28.4.1 • \\ UDK: 1:2-58 Welte, B. • Izvorni znanstveni rad \\ Primljeno: 28. srpnja 2020. Prihvaćeno: 2. prosinca 2020.
}

* Suzana Maslać, mag. theol., Katolički bogoslovni fakultet $\mathrm{u}$ Đakovu Sveučilišta J. J. Strossmayera u Osijeku, Petra Preradovića 17, p. p. 54, 31400 Đakovo,

Hrvatska, suzana. maslac@gmail.com

Sažetak: U svojoj filozofiji religije Welte je osobitu pozornost posvetio razmatranju onoga što on naziva »izvršenje religije «. Budući da je to izvršenje, medu ostalim, potaknuto i čovjekovim traganjem za smislom, prilog započinje Welteovim izlaganjem o nerazdruživoj vezi smisla i religije. Time se pak nužno dolazi do pojma Boga jer je On nositelj smisla. Na tragu njemačke mistike te posebno M. Eckharta, Welte se usteže Boga podvrgnuti svakoj kategorijalnosti te Ga označava pojmovima neizrecivi, beskonačni, skriveni. Kao onomu koji je neizreciv $i$ skriven, Bogu se pristupa molitvom i njezinim oblicima, čime se pokazuje da su upravo to autentični načini čovjekova odnosa prema Bogu: time smo došli do središnje komponente clanka, koja je sadržana u predstavljanju temeljnih aspekta welteovskoga videnja molitve - molitva kao šutnja, kao govor $i$ kao kult. Svaki od tih pristupa sadrži svoju osobitost: molitva šutnje nikako nije negacija istinskoga govora; molitvu govora pak u bitnome karakterizira dvopolnost, dok u kultu na poseban način do izražaja dolazi pojam zajednice i s njom okupljačka dimenzija govora. Prilog završava razmatranjem opasnosti u koje izvršavanje religije s obzirom na molitvu i kult može skliznuti. To, kako ga njemački filozof naziva, izopačenje religije predstavlja stari, a uvijek novi problem svake religije: $\gg$ Ovaj me narod časti samo usnama, a srce mu je daleko od mene.« $(M k 7,6)$

Ključne riječi: Bernhard Welte, Bog, religija, smisao, molitva, šutnja, govor, kult, izopačenje. 


\section{Uvodna razmatranja i postavljanje problema}

Središte filozofije religije jest Bog kao stvarnost. Welte je smatrao kako je upravo misao o Bogu presudna pretpostavka i temelj religije. ${ }^{1}$ Religija je određena Bogom, međutim kao što je ona određena Njime, tako je i govorom o Bogu potrebno govoriti o onome koji taj govor upućuje. Riječ je o čovjeku. Čovjek je taj i jedino je biće koje promišlja, govori i djeluje kroz kult s obzirom na Boga. Religija je, u izvjesnom smislu, čitav sklop međusobnoga djelovanja, u kojemu se čovjek odnosi prema Bogu na jednoj strani i u kojemu se Bog objavljuje čovjeku kroz znakove i simbole te određuje njegovo ponašanje na drugoj strani. ${ }^{2}$ Kada se na taj način govori o religiji, tada pri tome treba imati na umu čovjekovo religiozno ponašanje uopće. Pritom su njegova vjera, molitva i kult temeljni oblici religije. To su ljudski načini ponašanja koji na mnogostruk način proizlaze iz pretpostavke misli usmjerene na Boga i iz načina kako se Bog čovjeku očituje i suočava ga sa svojim zahtjevom. ${ }^{3}$ Svakako, molitvi i kultu u pozadini mora biti upravo vjera, koja se, u autentičnom smislu, ima uzeti kao conditio sine qua non čovjekova odnosa prema Bogu. $\mathrm{U}$ isto vrijeme vjera je, prema Welteu, humana osnova religije. ${ }^{4}$ Pojam humana njemački filozof shvaća u specifičnom smislu, to znači ne u strogoj ćudorednosti na koju taj pojam u svojem temeljnom značenju smjera. U religiji naime čovjek doživljava samoga sebe kao onoga koji je Bogom određen na način povjerenja te, uspostavljajući taj odnos iz te $\gg$ uvjetovanosti $\ll \mathrm{i} \gg$ intime $\ll$, istovremeno uviđa da je riječ o odnosu osobe prema osobi. Zbog toga upravo humani karakter. ${ }^{5}$

U tom smislu Welte najprije predstavlja nacrt prvoga puta prema Bogu kao bitnoj pretpostavci religije, koji ne želi biti dokaz za Božju opstojnost ni u tradicionalnom smislu ni u smislu egzaktne znanosti, nego u smislu puta na kojem vjernik može osmisliti svoju vjeru i govor o Bogu. ${ }^{6}$ Njemački se filozof ovdje u bitnome oslanja na M. Heideggera koji smatra da Bog koji je takvim dokazima postavljen kao siguran nije božanski Bog. ${ }^{7}$ Moderna znanost ne može dati dokaze za Božju opstojnost.

\footnotetext{
${ }^{1}$ Usp. B. WELTE, Filozofija religije, Zagreb, 2016., 83.; usp. također L. WITTGENSTEIN, Tractatus logico-philosophicus: s uvodom Bertranda Russella, Zagreb, 2004., 240.

${ }^{2}$ Usp. B. WELTE, Filozofija religije, 157.

${ }^{3}$ Usp. isto.

${ }^{4}$ Usp. isto, 158.

${ }^{5}$ Usp. isto, 53.

${ }^{6}$ Welte ovdje spominje Hansa Alberta i njegov kritički racionalizam koji je na Kantovu tragu. U tom se smislu ovdje govori o nemogućnosti ikakvih znanstvenih dokaza za Božju opstojnost.

${ }^{7}$ Usp. M. HEIDEGGER, Die onto-theologische Verfassung der Metaphysik, u: Identität und Differenz, Pfullingen, 1957., 35-73. i Brief über den Humanismus, Frankfurt a. M., 1949., 313-364.
} 
Govoriti o našem opstanku u svijetu ima smisla samo ako pritom shvatimo i to da tom opstanku pripada otvorenost iskustva. ${ }^{8}$

$\mathrm{Na}$ tom tragu, Welte daje nacrt drugoga puta prema Bogu, pri čemu je u središtu pozornosti Leibnizovo', Schellingovo i Heideggerovo temeljno metafizičko pitanje zašto jest biće, a ne radije ništa. Naime čovjeku je jasno da nekada nije postojao te mu se zbog toga nameće pitanje zašto onda uopće jest. To pitanje povlači daljnje pitanje zašto svijet uopće jest. A na to pitanje prirodne znanosti ne mogu dati konkretan odgovor jer se tu javlja tajna onoga već spomenutoga ništa kao zagonetnoga, tajnovitoga, bezuvjetnoga i beskonačnoga temelja svega što jest, koja pak nije predmet prirodoznanstvenoga istraživanja, nego slobodne odluke za smisao. Prihvaćajući stav da znanost ne treba hipotezu Boga, Welte dosljedno tomu smatra kako ta hipoteza nije uopće potrebna da bi se mogao objasniti svijet i njegov tijek, a niti za to da bi se njime moglo tehnički ovladati. To se još uvijek događa »etiam si Deus non daretur $\ll-$ kao da Boga nema. ${ }^{10} \mathrm{U}$ tom sklopu valja čitati Wittgensteinov izričaj da se Bog u svijetu ne objavljuje. ${ }^{11}$ Znanost se kreće na području empirijskoga svijeta i (konačne) logike, ali nije besmisleno tvrditi da taj svijet i logiku utemeljuje beskrajna Tajna, da ona »koja sve nosi i odlučuje ujedno nosi i odlučuje logiku svega «. Zbog toga upravo s druge strane ta hipoteza, prema njemačkom filozofu, ne gubi svoju relevantnost u kontekstu tajnovitosti sveukupne stvarnosti.

S obzirom na rečeno, postaje jasno da je smisleno prihvatiti svoju konačnost na jednoj strani te da nije besmisleno tragati za beskonačnošću, ispunjenom tajnom, na drugoj strani. Traganje za smislom štoviše je »ispunjeno živim interesom našega opstojanja « te se nameće svojevrsnom nužnošću postojanja, postavljanja pitanja i davanja odgovora. A budući da je ono angažirano, mi ne samo da pitamo o smislu nego redovito i djelujemo u tom pogledu. Traganje za smislom nadalje ne može biti samo privilegija racionalnoga opravdanja vlastita postojanja, kao i svijeta u kojem opstojimo. Pitanje smisla s obzirom na ono $\gg$ religiozno $\ll u$ čovjeku i kod čovjeka

${ }^{8}$ Usp. B. WELTE, Filozofija religije, 55.

${ }^{9}$ Leibniz je prvi, na izričit način, formulirao ontološko pitanje postojanja: zašto postoji to nešto, zašto je to što postoji upravo takvo, zašto ja postojim, zašto mi postojimo. Usp. G. W. LEIBNIZ, In der Vernunft begründete Prinzipien der Natur und Gnade, u: ISTI, Philosophische Schriften, (niz), I, Kleine Schriften zur Metaphysik, Darmstadt, 1965., 414-439. i 427.

${ }^{10}$ Usp. H. GROTIUS, De jure belli ac pacis, Prolegomena 11. To je metodičko polazište novovjekovne znanosti koja tamo, tj. u područjima gdje je ovladala cjelokupnim opstojanjem života, na kraju postaje nesposobna uopće postaviti pitanje o Bogu. O tome govori, kako i sam Welte navodi, C. BERNHARD u djelu: Die Unfähigkeit zur Gottesfrage im positivistischen Bewußtsein, Freiburg, 1972., 27-42.

${ }^{11}$ Usp. B. WELTE, Filozofija religije, 83. i L. WITTGENSTEIN, Tractatus logico-philosophicus s uvodom Bertranda Russela, 150. 
pokazuje da je život, iako konačan, sam po sebi (a ne samo Bog) ispunjen tajnovitošću i nedovršenošću. Čak su odricanje od smisla i odluka za besmisao mogući samo zato što se takve odluke, u vidu stavova i djelovanja, pokazuju za nekoga smislene. Stoga se može reći da vjera u beskonačnu i bezuvjetnu moć, koja svemu čuva smisao i o svemu odlučuje, može biti smislena, pa i razumski utemeljena vjera. ${ }^{12}$

Upravo taj vid, potraga za smislom te vjera $\mathrm{u} \gg$ bezuvjetnu $\ll$ moć očituje utemeljenost religioznih činova, odnosno očituje potrebu molitve i kulta, što znači izvršenja same religije. (Straho) poštovanje prema Svetomu, kao odlika svake religije i religioznosti, u najdubljoj se osnovi stavlja nasuprot onom sigurnom, to jest dokazanom i provjerenom, sa svih strana $\gg$ iskušanom $\ll$ i spoznajno $\gg$ konzumiranom «. Izvršenje religije u molitvi kao šutnji na jednoj i riječi na drugoj strani te kultu općenito smjera prema beskonačnom i bezuvjetnom koje, prema Welteu (i njegovu uzoru Eckhartu ${ }^{13}$ ), nije ni biće, ali ni ništa, nego apsolutna Tajna, koja se upravo zbog toga može nazvati Bogom te $u$ konačnici zaslužuje navedeno (straho)poštovanje. ${ }^{14}$ Pri tome to izvršenje u svojim oblicima šutnje, govora i činova očituje u isto vrijeme potragu za smislom.

Zazivanje i molitva pripadaju osnovama religioznoga ponašanja, tako da pitanje o Božjoj osobnosti dotiče i pitanje temelja religioznih čina. ${ }^{15}$ Božje boštvo za naše iskustvo temelji se u događajima objave i stoga ima poseban povijesni značaj. Vječna Tajna u svojoj epifaniji premašuje temeljnu razliku između nad-bića i bića te se tako daje u obrisima u poretku bića. ${ }^{16}$ Povijest religija najbolje svjedoči povijesnom mijenjanju Božjega lika prema vremenu i prostoru te čovjekova pokušaja prodiranja u tu Tajnu. Upravo je čovjek onaj koji se oslanja na Boga, potvrđuje ga, priznaje i u konačnici mu se obraća. Taj način čovjekova obraćanja Bogu, odnosno to, Welteovim riječima, izvršenje života, koje se događa u obraćanju Bogu, nazivamo upravo molitvom. ${ }^{17}$ Čovjek koji je vjernik ujedno mora biti i čovjek molitve, jer je to temeljni način ophođenja s Bogom. U tom smislu Welte dojmljivo ističe kako je vjera korijen religioznoga života, a molitva mu je cvat te ako vjera predstavlja temelj, molitva u isto vrijeme predstavlja izvedbu. ${ }^{18} \mathrm{Njemački} \mathrm{je} \mathrm{filozof} \mathrm{religije} \mathrm{svje-}$ stan da se molitva pokazuje $u$ različitim oblicima i kroz različite oblike pozivajući

\footnotetext{
${ }^{12}$ Usp. B. WELTE, Filozofija religije, 71.

${ }^{13}$ Welte cijelu jednu knjigu posvećuje misli Meister Eckharta. Riječ je o knjizi: Meister Eckhart Gedanken zu seinen Gedanken, Freiburg, 1992., 268.

${ }^{14}$ Usp. B. WELTE, Filozofija religije, 56-63.

${ }^{15}$ Usp. isto, 135-141.

${ }^{16}$ Usp. isto, 135.

${ }^{17}$ Usp. isto, 170.

${ }^{18}$ Usp. isto.
} 
se pri tome na Friedricha Heilera. ${ }^{19}$ Ono što je potrebno pri govoru o molitvi jest razlučiti bitne od njezinih nebitnih oblika. Bitnu molitvu spoznajemo kada uvidimo da je primjerena i tajni Boga i tajni čovjeka, pri čemu je zapravo sama molitva također tajna. ${ }^{20}$ Stoga je potrebno razmotriti najvažnije oblike molitve, koji su prema Welteovu tumačenju sljedeći: molitva šutnje, molitva kao govor i molitva kao kult. ${ }^{21}$ Oni su predmet naših razmatranja.

\section{Molitva šutnje}

Molitvu šutnje označavamo kao onu najmanje izražajnu, jer kako sam naziv govori, ona se odvija u šutnji i s njom pripadajućoj tišini, pri čemu onaj koji se Bogu tako obraća ima u vidu neizrecivost i nedokučivost tajne koja ga nadilazi. Molitva šutnje jest najautentičnije priznanje te nedokučivosti. Čovjek svoju riječ zadržava u šutnji. Nijema je šutnja stoga prvi lik molitve i u njoj se smrtni čovjek najprimjerenije odnosi prema Bogu, prvoj i vodećoj odrednici svake religije. ${ }^{22}$ Takav oblik molitve, molitva šutnje, bio je često opisivan u zapadnoj kršćanskoj tradiciji, napose u mistika. Meister Eckhart ovdje služi kao eklatantni primjer. Welte također spominje i jednu od najvećih svjetskih religija, budizam ${ }^{23}$, koji upravo svoju religioznost živi

${ }^{19}$ Usp. F. HEILER, Das Gebet: eine religionsgeschichtliche und religionspsychologische Untersuchung, München, 1920., 300-350.; B. WELTE, Filozofija religije, 170.

${ }^{20}$ Usp. B. WELTE, Filozofija religije, 170.

${ }^{21}$ Welte tumači izraz der Kult kao onaj koji označava sveukupnost činova kojima se iskazuje štovanje Bogu; za razliku od bogoslužja (liturgije), koje ima uže značenje glavnih bogoštovnih činova (služba Božja). U hrvatskom kult pokriva značenje bogoštovlja i bogoslužja bez razlike. Osim u rijetkim iznimkama i zbog stilskih razloga ovdje Welte ne rabi te izraze, jer im je značenje isključivo vezano uz monoteističke religije, u prvom redu uz kršćanstvo i jer se uobičajeno koriste u kršćanskom teologijskom kontekstu, dok je ovdje bitan kontekst religijsko-filozofijskoga razmatranja.

${ }^{22}$ Usp. B. WELTE, Filozofija religije, 172.

${ }^{23}$ Budizam je religijski sustav nastao u Indiji u VI. i V. st. pr. Kr. (oprječan vladajućemu brahmaniz$\mathrm{mu}$ ), osnovan na učenju Siddhārthe Gautame. Glavni sadržaj učenja (dharma) tvore »četiri plemenite istine « (catvari ärya satyāni) o patnji, nastanku patnje, prestanku patnje i oslobođenju od patnje. Život je patnja (duhkha), uzrok su patnji želja (volja, žeđ, tršnnāa) i neznanje (avidya), koji stalnim nemirom, kao načelom uzročnosti (karman), određuju sudbinu svakoga čovjeka i stvaraju neprekidni krug rađanja i smrti (samssāra), tj. ponovnih utjelovljenja, koja su opet patnja. Čovjek se toga može osloboditi postizanjem nirvāne (utrnuća, ugasnuća), tj. odvraćanjem od svega što vezuje uz život. Tomu vodi »osmeročlani put « (ašțānga mārga), tj. prava vjera, prava odluka, pravi govor, pravo djelovanje, pravo življenje, prava težnja, pravo mišljenje i prava usredotočenost. Čovjek je, prema budizmu, tek privremeni zbir pet nakupina (skandha): oblika ili fizičkoga tijela (rūpa), osjećaja (vedanā), percepcije ili razumijevanja (saṃjũa), volje (samıkāra) i čiste svijesti (vijñāna). Njihove su značajke rođenje, starost, smrt, trajanje i mijenjanje; bez esencije su (anātman), bez stalnosti (anitya), prazne (šūnya) i obilježene patnjom (duhkha). Budizam pitanje supstancije i duše smatra iluzornima, pa se katkad i određuje kao religija bez boga ili bez duše. Budizam se suprotstavlja 
posve iz molitve šutnje ${ }^{24}$. Neke od karakteristika molitve šutnje jesu: negativnost šutnje kao odijeljenost, pozitivnost šutnje kao sabranost, pozitivnost šutnje kao pobožnost te obrat (molitvene) zahvale u šutnji, čime se postiže cjelina.

Prva karakteristika molitve šutnje jest njezina »negativnost «. Negativna je u smislu da predstavlja izuzimanje od svega što karakterizira (današnji) život prepun jurnjave i raznoga govorkanja. Ona se ne bavi ničim i ne da se natjerati u puko isprazan govor. Ona predstavlja tišinu duha, što je zapravo druga riječ za cijeloga čovjeka. ${ }^{25}$ Kroz negativnost šutnje čovjek pušta da utihnu nagoni i opsjednutost svijetom, kao i njegova znatiželja te postaje tišina i opuštenost. Kao primjer Welte ovdje ponovno uzima M. Eckharta koji govori o tome da čovjek mora postati jednak onomu ništa. ${ }^{26}$

Kao druga karakteristika molitve šutnje očituje se pozitivno prešućena pozitivnost. Ona je najprije pozitivnost spremnosti; to je čisto slušanje, koje doduše ne čuje nikakvo konkretno nešto, ali je otvoreno i spremno čuti sve. Iz pozitivnosti proizlazi sabranost, sabranost iz raspršenosti ovoga svijeta. Ona pri tome nije bez svijeta ili odijeljena od svijeta, što prije svega znači kako nije zapala u svijet. ${ }^{27}$ Posebnu vrijednost riječ sabranost dobiva u religioznom smislu. U tihom prostoru šutljive spremnosti sve je sabrano, sav vanjski i sav unutarnji svijet, sve diše u tome $\gg$ sabrano « i s njim u onom slobodno. ${ }^{28}$ Dovodeći pojam sabranosti u vezu s pojmom slobode, možemo reći kako sabranost ima bitno, osim religiozne, i antropološku kategoriju. Riječ je o najizvornijem smislu slobode, o slobodi duha, pri čemu je u (šutljivom) sabranju na djelu sebe-sabiranje, sebe-objedinjavanje. Sabranost je dakle u kontekstu slobode u Welteovu (te još više Eckhartovu) smislu jedno više stanje smirenosti, i unutarnjega i vanjskoga svijeta. $U$ tom se smislu ta sabranost i s njom povezana smirenost očituju kao uvjet istinske slobode, koja je za Weltea čista

vladajućemu brahmanizmu nepriznavanjem kasta, obreda i askeze, a žrtvovanju životinja pretpostavlja samilost, strpljivost i samoodricanje. U predstavljanju budizma u bitnome smo se poslužili mrežnom stranicom: https://www.enciklopedija.hr/natuknica.aspx?ID=9995 (20. 6. 2020.).

${ }^{24} \mathrm{Uz}$ temu svjetskih religija i posebice budizma treba svakako imati u vidu Welteovu knjigu Das Licht des Nichts. Von der Möglichkeit neuer religiöser Erfahrung, H. Zaborowski (ur.), Kevelaer, 2015., 94.

${ }^{25}$ Usp. B. WELTE, Filozofija religije, 173.

${ }^{26}$ Usp. M. ECKHART, Deutsche Werke, I, J. Quint (ur.), Stuttgart, 1958., 107. Pojam ništa u kontekstu molitve šutnje ovdje ima za cilj upozoriti na zahtjev smiraja koje je analogno umiranju: pasivnost kao primateljska kategorija.

${ }^{27} \mathrm{Na}$ ovome mjestu Welte spominje još jednoga autora, Franza von Baadera, koji za sabranost, koja biva slobodna od svijeta, govori kako je to ista ona koja nije zapala u svijet. Usp. također: D. F. M. STRAUSS, Intellectual influences upon the reformational philosophy of Dooyeweerd, u: Philosophia reformata 69(2004.), 151-181.

${ }^{28}$ Usp. B. WELTE, Filozofija religije, 174. 
otvorenost. Iz te čiste slobode i otvorenosti ta sabranost (čovjek), kao njezin uvjet, obuhvaća sav svijet, ali ga ujedno i bitno nadilazi. ${ }^{29}$

Treća karakteristika molitve šutnje jest pozitivnost šutnje kao pobožnost. Riječ pobožnost među ostalim odredbama pripada religioznom jeziku i kao takva se i upotrebljava. U Hegelovoj filozofiji religije ta je riječ igrala značajnu ulogu. ${ }^{30}$ Riječ Andacht ${ }^{31}$ označava čovjekovu usmjerenost $\mathrm{k}$ Bogu kroz vrijeme, kao i formu života koja se u toj usmjerenosti oblikuje: pobožan je onaj koji je po Božjem, jer se sav pruža Bogu; odatle onda po-božnost, dakle po Božjem, kao stav, držanje i odgovor Bogu, koji je prethodno na način objave oslovio čovjeka. ${ }^{32}$ Welte smatra kako se upravo u pobožnosti ispunja molitva šutnje. Tek u tome ona je potpuna molitva i molitva u punom smislu. U tranzitivnosti živoga odlaženja od sebe i prelaženja onom vječnom nalazi se ono cijelo i ono najviše. ${ }^{33}$ To pogađa čitav čovjekov život i cjelinu njegova opstanka. Ta cjelina u sebi ima određeni okret koji Welte naziva obrat zahvale i krug religije. Tek u tom okretu ispunjava se cjelina i ono najviše što pripada molitvi. Kada bi molitva šutnje govorila, mogla bi reći sljedeće: $\gg$ Ti si me darovao meni i sada mi, u trenutku molitve, daruješ to da se ja darujem tebi i to je okret, okret živi bez govora i prisutan je u šutnji. $\ll^{34} \mathrm{O}$ pobožnosti religioznoga čovjeka može se reći kako je to jedan živući cirkularni proces jer pobožnost kao kretanje uvijek odgovara izvornijem kretanju koje mu je već (oduvijek) izišlo u susret. Ona izvršava i su-izvršava ono što se izvršava po sebi i što se oduvijek već izvršilo polazeći od onoga vječnoga $\gg \mathrm{Ti} \ll .{ }^{35} \mathrm{To}$ Hegel naziva ono spekulativno u pobožnosti, sraz različitih kretanja u pobožnosti, koji ako se razumije u pogledu molitve šutnje, daje nam spoznati njezinu vrijednost i životnost. ${ }^{36}$ Kao stav, pobožnost nužno uključuje vrlinu poniznosti koja je uvijek »zahvalna « za ono što ima i što prima. $U$ tom smislu događa se spomenuti molitveni (obrat) zahvale u šutnji: nikakve riječi ne mogu obuhvatiti zahvalnost koju pobožan čovjek doživljava prema Bogu zbog primljenih darova. Pobožan čovjek zbog toga ostaje »zapanjen $\ll$ zbog veličanstve-

\footnotetext{
${ }^{29}$ Usp. B. WELTE, Filozofija religije, 174.

${ }^{30}$ Usp. G. W. F. HEGEL, Vorlesungen über die Philosophie der Religion I/1, G. Lasson (ur. i. izd.), Hamburg, 1966., 235-240.

${ }^{31}$ Andacht se rabi u njemačkom jeziku za pojam pobožnosti.

${ }^{32}$ Usp. B. WELTE, Filozofija religije, 175.; opaska prevoditelja S. Kušara.

${ }^{33}$ Usp. isto, 175.

${ }^{34}$ Isto, 176.

${ }^{35}$ Usp. isto.

${ }^{36}$ Usp. G. W. F. HEGEL, Vorlesungen über die Philosophie der Religion I/1, 240.; B. WELTE, Filozofija religije, 176.
} 
nih Božjih darova, tako da šutnja »najbolje « otkriva o kakvoj je darovanosti riječ. Time se, kako je natuknuto, u molitvi šutnje postiže cjelina.

\section{Molitva govora}

Molitva šutnje velika je, ali ona uvijek ostaje unutar granica ljudske mogućnosti. Unutar te granice nalazi se i molitva kao govor. ${ }^{37}$ Religija i molitva ljudski su oblici ponašanja, u njima se čovjek odnosi prema Bogu, stoga ni molitva kao govor ne može izostati. ${ }^{38}$ Welte će kazati kako tek kroz govor naš opstanak dostiže svoju puninu, primjerenu jasnoću i čvrstoću. ${ }^{39}$ Šutnja i tišina, u izvjesnom smislu, također pripadaju molitvi govora. Riječ je o tijeku misli. Bog nas kao ljude pogađa u cjelini i sve dimenzije našega bića. $U$ tom smislu kroz molitvu govora razvija se naša komunikativna bît jer moleći, na koji god način, govorimo Bogu, obraćamo mu se. U molitvi kao govoru ljudi se obraćaju, govore Bogu is Bogom, Bog biva imenovan i oslovljen i čovjek mu se također intimno povjerava..$^{40}$ Ako je Bog imenovan, ako se molitva zbilja izgovara, onda tajna Boga ima svoju jasnu prisutnost u zajedništvu ljudi. ${ }^{41}$ Šutnja i njezina pobožnost kao unutarnja dimenzija molitve te govor kao vanjsko izražavanje unutarnjosti uvijek pripadaju zajedno. O religioznom jeziku i molitvi kao govoru Welte spominje vrijedne publikacije, odnosno autore koji nam pokušavaju približiti tu stvarnost. ${ }^{42}$ Kada je riječ o govoru općenito, njemački se filozof poziva na autore poput Liebrucksa i Caspera te dodaje kako se u diskursu o govoru i govornicima u novijoj jezičnoanalitičkoj literaturi češće govori o trosmjernoj semantičkoj relaciji koja predstavlja relaciju prema govorniku, prema slušatelju te prema stvari o kojoj se govori. ${ }^{43} \mathrm{Za}$ razliku od toga, u molitvi je riječ o svojevrsnoj dvo-polnosti. Ona s jedne strane ima teološki pol, dok s druge ima antropološki. Teološki pol jer se govori Bogu, a antropološki jer je riječ o čovjeku koji govori Bogu. S obzirom na rečeno, ovdje u bitnome iščitavamo relacijski

\footnotetext{
${ }^{37} \mathrm{Njem}$. die Sprache jest korelat šutnji, prevodimo ga kao govor i kao jezik. Govor u smislu sustava znakova pomoću kojih se odvija komunikacija među ljudima. Jezik pak kao najopćenitiji sustav znakovnoga, glasovnoga, pismenoga izražavanja.

${ }^{38}$ Usp. B. WELTE, Filozofija religije, 177.

${ }^{39}$ Usp. isto.

${ }^{40}$ Usp. isto, 179.

${ }^{41}$ Usp. isto, 178.

${ }^{42}$ Usp. E. SCHILLEBEECKX, Glaubensinterpretation. Beiträge zu einer hermeneutischen und kritischen Theologie, Mainz, 1971., 376-379.; G. EBELING, Einführung in die theologische Sprachlehre, Tübingen, 1971., 264.; B. CASPER, Sprache und Theologie. Eine philosophische Hinführung, Freiburg i. Br., 1975., 87.

${ }^{43}$ Usp. B. WELTE, Filozofija religije, 179.; B. LIEBRUCKS, Sprache und Bewußtsein, I, Frankfurt a. M., 1964., 218.; B. CASPER, Sprache und Theologie, 87.
} 
značaj molitve kao takve, koja je uvijek upravljena prema Bogu, očitujući u isto vrijeme načelo istinskoga pouzdanja i povjerenja koje osobe (čovjek - Bog) u tom odnosu razvijaju.

Povrh rečenoga, valja spomenuti da molitva dotiče i negativan govor koji zapravo vodi k tomu da negacijama riječi u molitvi uzveličamo onoga komu se obraćamo, Boga. Ako je Bog oslovljen kao beskonačan, kao bezuvjetan i neizreciv, onda se upravo negacijama tih riječi upozorilo na tajnu koja je veća od svih riječi. Jezičnim oblikom negacije jezik transcendira vlastite granice, granice svoje konačnosti. ${ }^{44}$ Druga jezična mogućnost molitve jest oslovljavanje, tj. imenovanje Boga $u$ afirmacijama, što predstavlja pozitivno-simbolični govor. U njoj se Bog pozitivno imenuje u simbolima. Te pozitivne riječi imaju funkciju simbola, što znači da u njima značenja padaju zajedno (što simbol i predstavlja, znači). Upravo je simbolički govor $\gg$ najzahvalniji $<\mathrm{u}$ pristupu $\mathrm{k}$ Bogu, jer $\mathrm{s}$ jedne strane simbol je u mogućnosti iskazati pozitivnu konačnu riječ i ono što ona pozitivno kazuje i imenuje te s druge strane neiskazivo i neizrecivo Božje $\gg \mathrm{Ti} \ll$, Boga koji u toj riječi treba biti zazvan. ${ }^{45}$ Kada je nadalje riječ o vezi simboličnoga govora i molitve, treba istaknuti to da je Bog uvijek veći, potpuniji, savršeniji (Deus semper maior) od svega što se može izreći, odnosno predočiti simbolom. Welte se upravo zbog toga ovdje poziva na Karla Jaspersa i njegov govor o simbolu kao šifri. Jaspersova šifra jest kodirano pismo, koje kazuje šifru transcendencije, tj. Boga, i ono nikada ne može biti razriješeno. Jaspers će naime, reći kako je ta šifra čitljiva za moguću egzistenciju, što znači da egzistirajući čovjek, onaj koji je postao svjestan toga da stoji pred Bogom i kojega ta svijest preobražava te on $u$ tom smislu postaje egzistencijom, iščitava, odnosno dekodira do izvjesne granice šifru, čime u prolaznim riječima, iako djelomično, ipak prodire u neprolazni smisao, tajnu Boga. ${ }^{46}$

U svojoj znamenitoj studiji Die Würde des Menschen und die Religion ${ }^{47}$ Welte upozorava i na to da u današnjem svijetu govor molitve teško dolazi do izražaja, upravo iz razloga što je potisnut, no ipak čeka na dnu ljudskoga srca. Jezik molitve i simbola postao je dakle težak, ali ne sasvim nemoguć. Kada se pitamo kako onda treba osloviti Boga, Welte kaže kako lijep sažetak mogućega odgovora na to pitanje

\footnotetext{
${ }^{44}$ Usp. B. WELTE, Filozofija religije, 181.

${ }^{45}$ Usp. isto.

${ }^{46}$ Usp. K. JASPERS, Philosophie (zweite, unveränderte Auflage), Berlin - Göttingen - Heidelberg, 1948., 705-774.

${ }^{47}$ Usp. B. WELTE, Die Würde des Menschen und die Religion, Regensburg, 2017., 85-93.
} 
daje Grgur Nazijanski u dvama redcima: »Sveimeni, kako da te zovem. Ti, jedini Bezimeni! $\ll^{48}$

Nadalje, kada je riječ o antropološkom polu molitve, treba reći kako onaj koji moli oslovljava u molitvi najprije Boga, ali to čini tako da svojim oslovljavanjem ujedno izriče i sama sebe te se $u$ »igru « nužno dovodi i čovjek. ${ }^{49}$ Tamo gdje se čovjek kao on sam te ogoljen u svojoj bîti otvara Bogu, morat će sa sobom uz riječi dovesti i svoj sadržaj, svoj svijet, konačno sebstvo. Takva molitva treba se odlikovati iskrenošću i cjelovitošću. Iskrenošću nedostatnosti jer nije sama po sebi razumljiva i cjelovitošću jer ju je potrebno prihvatiti kroz vjeru i ufanje. ${ }^{50} \mathrm{U}$ rečenicama psalama dade se posebice iščitati izlijevanje srca gdje se ništa ne zadržava u sebi, već, pokrenuti riječima psalama, naša je »obveza « prianjati uz Boga, i u trenutcima Njegove posvemašnje odsutnosti. ${ }^{51}$

Potpunost je još jedna karakteristika koja uz iskrenost biva zajednička molitvi i vjeri. Ono potpuno, cijelo, sve što jesam i što je u meni, treba se u govoru molitve otvoriti Bogu. ${ }^{52}$ To potpuno obuhvaća sve ono što ja jesam, moje brige, strahove i nadanja, $u$ konačnici cjelovitost mojega sebstva, u kojemu se moleći izlijevam pred Bogom.

Iz predočenoga je razvidno kako upravo molitva otkriva svu dubinu relacijskoga značaja jezika. Naime relacijski značaj jezika očituje kako onaj koji moli Boga uvijek oslovljava njegovim simboličnim imenima te, izričući time sebe i cijeli svoj svijet, $s$ Njim ulazi u izniman odnos. ${ }^{53}$ Konačno, sama odnosnost govorne molitve razvija se, kako nas Welte poučava, u mnoštvu konkretnih modaliteta: na način klanjanja i hvale, na način zahvale i molbe, konačno na način tužaljke i naricanja. ${ }^{54}$ Pri tome, zanimljivo, filozof religije u okviru molitve kao pobožnosti posebno ističe zahvalu. Naime, onomu tko moli, Bog prvotno daruje molitvu zajedno s jezikom molitve, pa samo zato taj tko moli može darovati Bogu svoju pobožnost skupa s riječima te iste pobožnosti. Upravo iz toga razloga bîti molitve pripada da je ona uvijek (i) zahvala. ${ }^{55}$

\footnotetext{
${ }^{48}$ GRGUR NAZIJANSKI, Carmina (dogmatica) 1, 1, 29.: PG 37, 508. U istoj pjesmi upućenoj Bogu Grgur mu se obraća sljedećim riječima: Budi dobrostiv, Ti koji si Onostranost svega. Ovdje (ponovno) upozoravamo na eckhartovski utjecaj na Weltea, gdje njemački mistik, kao i kasnije B. Welte, Boga ne podvrgava kategorijalnosti.

${ }^{49}$ Usp. B. WELTE, Filozofija religije, 186.

${ }^{50}$ Posebice Ps 62, 9, gdje stoji: »Izlijte svoje srce pred Bogom!«

${ }^{51}$ Ovdje Welte posebice ističe Ps 22, gdje molitelj moli sljedeće: »Bože moj, vičem danju, al' ne odvraćaš, vapim noću i nema mi počinka.«

${ }^{52}$ Usp. B. WELTE, Filozofija religije, 187.

${ }^{53}$ Usp. isto, 188.

${ }^{54}$ Usp. isto, 190.

${ }^{55}$ Usp. isto, 191.
} 


\section{Molitva kao kult}

Molitva šutnje ukida $\mathrm{se}^{56}$, to jest dovršuje $\mathrm{u}$ molitvi kao govoru, a molitva govora u molitvi kao kultu. Welte je smatrao kako tek u kultu prepoznajemo onu visoku i posebnu mogućnost koja se nalazi u molitvi kao govoru. Kult se događa kao izvršenje zajednice; on je izvršenje i prikaz zajednice u kojoj se odvija. ${ }^{57}$ Zajednica je pri tom zbor ljudi koji su zajedno pogođeni Bogom te zbog te pogođenosti zajedno slave Boga. Bitak zajednice predstavlja biti jedan s drugim, biti u zajedništvu. Ovdje je prisutan dvostruki odnos posredovanja: s jedne strane Bog je taj oko kojega se zajednica okuplja i koga slavi, dok s druge strane svaki pojedinac, ako Bog »živi« u njemu, može živjeti tu cjelinu u zajedništvu s Bogom. Unutar zajednice uvijek je vidljivo jedinstvo unutarnjosti i javnosti. Svatko će moliti i vjerovati kao on sam, međutim kult omogućuje da to bude bitno zajedničarski događaj. Zbog toga se sebstvo ne može u kultu (okolo) rasplinjavati. ${ }^{58} \mathrm{U}$ tom smislu svatko zauzeto vjeruje i moli u okviru zajednice kojoj pripada, a taj otvoreni prostor, koji sve obuhvaća i koji svakoga otvara prema svakomu, nazivamo javnošću zajednice. ${ }^{59}$ Javnost zajednice uvijek se iskazuje riječju i zbiva se pomoću riječi. Welte će reći kako molitva utemeljuje tu javnost kao bitak-za (za sve i svakoga) i kao bitak-sa (sa svima i svakim) ${ }^{60}$ Potrebno je reći i kako okupljanje zajednice na sabranost i molitvu ipak treba određenu podjelu uloga, pri čemu se posebno ističe pojedinac kao predvodnik, svećenik, koji svojom riječju vodi zajednicu. Krug religije pritom jest upravo zbivanje molitve na način da prvo moli onaj koji je pozvan od Boga i njime pogođen, a onda on nastoji u svojoj molitvi dodirnuti Boga.$^{61}$ To je ujedno i riječ navještaja.

Kada je riječ o naviještanju, treba također istaknuti kako postoji antropološki i teološki vid naviještanja. Antropološki pol tiče se govora jednoga čovjeka drugima u zajednici, da bi ih svojim govorom dirnuo i pogodio. Teološki pol odnosi se na Boga koji je sadržaj toga govora. Za navjestitelja Welte kaže kako onaj tko navješćuje mora u svojem navješćujućem govoru najprije biti on sam, mora govoriti kao on

\footnotetext{
${ }^{56}$ Kod Weltea njem. izraz aufheben i imenica Aufhebung znači isto kao kod Hegela ukinuti u kvalitativno potpunijem smislu nego je to (tek) negacija. Ukinuti, shodno rečenom, znači uzdići, sačuvati, dovršiti; nešto se na jednoj razini ukida, da bi se uzdiglo na drugu, višu i ondje u preobraženom obliku sačuvalo kao cjelovito. Kult je primjerice molitva. Međutim on se ne iscrpljuje sav u molitvi, već su tu u bitnome na djelu činovi, ponašanje, koji samu molitvu preobražavaju (tj. u jednom dijelu ukidaju) u jednu višu dimenziju.

${ }^{57}$ Usp. B. WELTE, Filozofija religije, 193.

${ }^{58}$ Isto.

${ }^{59}$ Isto, 194.

${ }^{60}$ Isto.

${ }^{61}$ Usp. isto, 195.
} 
sam te mora govoriti uime i po nalogu Boga. ${ }^{62}$ Misli se na riječ koja je od Boga opunomoćena. Kao model za to Welte spominje Augustinove Ispovijesti koje predstavljaju ispovijesti osobnoga, sudbinski bogatoga poistovjećenja polazeći od Boga koji je veći od osobne sudbine, a ipak je živ u osobnoj sudbini jednoga pojedinca. ${ }^{63}$

Sjedinjenje koje je u temelju govora naviještanja biva nošeno nalogom i hranjeno sjećanjem. Kada je riječ o nalogu, treba reći kako nalog uzdiže onoga koji navješćuje nad kolebanja njegova osobnoga poistovjećenja. Nalog čini postojanim poistovjećenje, a ta se postojanost iznutra hrani sjećanjem. ${ }^{64}$ Model za tu funkciju sjećanja, koja čini postojanim, Welte ponovno pronalazi kod Augustina (Ispovijesti VII, 17.). On priznaje da nije mogao ostati stajati u svojem prosvjetljujućem iskustvu Boga - non stabam frui deo meo - ali da mu je sjećanje ostalo uz to iskustvo te ga je ono, nepostojanoga u toj stvari, učinilo postojanim: (M)ecum erat memoria tui. ${ }^{65}$

Još jedan bitan pojam kod Weltea kada je riječ o naviještanju i molitvi kulta jest kolektivno sjećanje. Riječ je o događajima koji su se zbili u prošlosti, ali oni uvijek iznova, obnavljajući se, trajno svijetle u sjećanju vjere svakoga pojedinca unutar zajednice. Konačno, za naviještanje je nezaobilazno jezično jedinstvo sa zajednicom. Jezik zajednice jest jezik kojim ljudi međusobno komuniciraju. Na prvi pogled čini se površan, međutim on sadrži zadivljujuću dubinu, a kako bi pokazao o kakvoj je dubini riječ Welte upućuje na Sigmunda Freuda i njegovu metodu analiziranja jezika njegovih pacijenata radi razotkrivanja podzemnih slojeva i pozadina toga jezika, dok je Paul Ricoeur odatle izvukao važne elemente za svoje »umijeće interpretiranja $\ll^{66}$. Riječ navještaja ima stoga zadaću dotaknuti i podignuti čovjeka, preobraziti ga i pokrenuti na konkretno djelovanje. ${ }^{67}$ Molitvom zajednica dakle uvijek slavi Boga, to je jedno dijaloško zbivanje te svi zajedno sudjeluju u živoj komunikaciji sa svima. Boga treba shvatiti i prihvatiti kao Boga svih i svakoga pojedinog. U konačnici treba reći kako je smisao kulta u zbivanju koje nazivamo communio živa zajednica Boga s ljudima i ljudi s Bogom, ali, ne manje važno, i ljudi međusobno. ${ }^{68}$

\footnotetext{
${ }^{62}$ Usp. isto, 196.

${ }^{63}$ Usp. isto, 197.; Usp. također: AURELIJE AUGUSTIN, Ispovijesti, Zagreb, 2012., 327.

${ }^{64}$ Usp. B. WELTE, Filozofija religije, 198.

${ }^{65}$ Usp. AURELIJE AUGUSTIN, Ispovijesti, 23.

${ }^{66}$ P. RICOER, Interpretation. Der Versuch über Freud, Frankfurt a. M., 1969. i J. RÜTSCHE, Freud in der französischen Philosophie, u: Philosophische Jahrbuch 78(1971.), 401-422.

${ }^{67}$ Usp. J. L. AUSTIN, Zur Theorie der Sprechakte, Stuttgart, 1972., 190-209.

${ }^{68}$ Usp. B. WELTE, Filozofija religije, 205.
} 


\section{Umjesto zaključka: Riječ i kult kao opasnosti izopačenja religije}

Predstavljajući temeljne aspekte molitve is njom posebno kulta, Welte je bio svjestan mogućnosti njihova izopačenja. Opasnost je to koja je pratila čovječanstvo od njegovih početaka: ustrajavanje na formi te odmak od bîti religije. ${ }^{69}$ Ta izopačenost krije se u razlici između njezine unutarnjosti i njezina vanjskoga izražavanja, zbog čega se i u Bibliji često javlja kritika religije: »Narod me ovaj usnama časti, a srce mu je daleko od mene « (Mt 15, 8; Mk 7,6). Za razliku od ateizma, koji otklanja i samu mogućnost, kao i svaki oblik Boga i s njim religije, taj je vid izopačenja religije mnogo suptilniji i teže uočljiv. Upravo zbog toga, prema Welteu, kult u sebi i krije najveću opasnost za religiju. Razlog tomu jest punina vanjskoga izražavanja koja se vrlo lako može odmaknuti od izvršenja bîti te tako postati izvanjskom, međutim, u konačnici, ipak sačuvati oblik religije. ${ }^{70}$ Iako se, kako je naznačeno, u svojem izopačenju kult ne može poistovjetiti s ateizmom, on ipak ovomu dolazi vrlo blizu: riječ je naime o štovanju koje to nije jer je na djelu izostanak vjere i pobožnosti, što pak u konačnici znači izostavljanje samoga Boga iz kulta. Odatle dodirne točke $s$ ateizmom.

Do takvih vidova izopačenja religije dolazi zbog čovjekova nagnuća prema moći, koju on želi proširiti preko svih ovozemaljskih granica i mogućnosti. Upravo se ovdje očituje izostavljanje Boga kao moći te se namjesto njega ističe vlastita moć $i$ pokušaj njezina ostvarenja. Izopačenje kroz molitvu i kult, o kojem se ovdje govori, za posljedicu ima, prema Welteu, konkretne (vidljive) obrise, koji su, prema našem autoru, sadržani u sljedećem: umnažanje vanjskoga bez bîti (supstancije), religija kao ideologija i religiozni fanatizam.

Prvi oblik izopačenja religije krije se u umnažanju vanjskoga izražavanja religije. Ona nastaje tako da čovjek čvrsto drži ono dohvatljivo u govoru religije i osobito kulta te zanemaruje ono bitno koje pri tome treba doći do izražaja, prije svega vjeru i pobožnost. ${ }^{71}$ Umnogostručavanjem oblika, bez istinske vjere i pobožnosti, dolazi se do toga da čovjek samoga sebe uzdiže i čini važnim u obliku religije. Religija kao ideologija jest drugi oblik mogućega izopačenja, gdje je religija svedena na instrument za postizanje estetskoga užitka. Korijen takve ideologije može se pronaći u čovjekovoj vjeri u samoga sebe i vlastite ciljeve, gdje vjera ostaje tek nešto usputno, dok se s druge strane događa apsolutizacija sebstva u izvršenju religije. Čovjek je ovdje onaj koji želi biti svemoćan i jednak Bogu, no u konačnici doživljava razočaranje jer postaje svjestan da su sredstva kojima raspolaže nedostižna. Welte ovdje

\footnotetext{
${ }^{69}$ Usp. isto, 220.

${ }^{70}$ Usp. isto, 221.

${ }^{71}$ Usp. isto, 222.
} 
posebno ističe mislioce poput Karla Marxa i Maxa Horkheimera, u čijim se djelima može naći dobar pregled povijesti pojma ideologije kroz prizmu religijsko-filozofijskoga polazišta. ${ }^{72}$ Treći vid izopačenja prema Welteu jest religiozni fanatizam, koji predstavlja krajnje opasnu i još radikalniju apsolutizaciju čovjekova odnosa prema tajanstvenom bezdanu Boga koji je jedini apsolutan. ${ }^{73}$ Ovdje je riječ o čovjekovoj nakani za apsolutiziranjem odnosa čovjeka i Boga, pri čemu umišljaj vlastitoga (i jedincatoga) izabranja, među mnogim mogućim drugima, vodi k samodopadnosti i isticanju. Krajnja posljedica pak te vrste izopačenja jest radikalni preokret: od »tvrde « uvjerenosti i sigurnosti događa se strmoglavi pad u tjeskobu. Ovdje je Welte posebno upozorio na vrijedna razmatranja S. Kierkegaarda i njegov pojam tjeskobe i antipatije. Kierkegaard je tu vrstu tjeskobe nazvao antipatetičnom simpatijom i simpatetičnom antipatijom. ${ }^{74}$ Ona je simpatija jer bi čovjek strastvenošću vlastita srca htio bezuvjetnost istine i sreće, odnosno htio bi potpuno $\gg$ konzumirati « Boga, međutim Bog mu, nakon (netom prikazana) razočaranja, postaje jedno strašno ništa. ${ }^{75}$ Stoga je tjeskoba ujedno i antipatija, jer se čovjek, da bi postigao tu bezuvjetnost istine i sreće, mora predati tajni koju nikada ne može pojmiti i koja mu zato (ponekad) izgleda kao ništa i trajno uzmiče. ${ }^{76}$ Takvu napetost moguće je riješiti jedino skokom u vjeru kao što je to Kierkegaard u svojim djelima učinio. Čovjeka duboko pogađa to da ne može sve znati i da je njegova volja konačna i uvjetovana te samomu sebi često »pomaže « na način da sve proziva prividom i da konačnost ne postoji, nema je.

Misli o izopačenosti religije uvijek i iznova upozoravaju na to da religija ima ugroženi položaj između čovjekovih najviših i najmračnijih mogućnosti. No, u konačnici, ispravljanje svih izopačenosti vodi opet do tajne Boga, pri čemu valja biti svjestan da se to $\gg$ ponovno vraćanje na pravi put izvršenja religije $\ll$, odnosno ispravljanje njezinih izopačenja, ne događa »od ljudi « i njihove moći, već samoga Boga. Potonje upravo svjedoči, ponovimo, kako je Bog bio i ostao središte Welteove filozofije religije, koji je, u konačnici, jedini i istinski čuvar njezine supstancije, odnosno zaštitnik od svih vrsta izopačenja.

\footnotetext{
${ }^{72}$ Usp. N. BIRNBAUM, Die Religon in Geschichte und Gegenwart, III, Tübingen, 1959., 567-572.; o Horkheimeru posebno u: A. SCHMIDT, Kritische Theorie. Eine Dokumentation, II, Frankfurt a. M., 1968., 375.

${ }^{73}$ Usp. B. WELTE, Filozofija religije, 225.

${ }^{74}$ Usp. S. KIERKEGAARD, Der Begriff Angst. Übersetzt und mit Glossar, Bibliographie sowie einem Essay »Zum Verständnis des Werkes« herausgegeben von L. Richter, Hamburg - Berlin, 2002., 150-202.

${ }^{75}$ Usp. B. WELTE, Filozofija religije, 226.

${ }^{76}$ Usp. isto, 226-227.
} 


\title{
PRAYER OF SILENCE, SPEECH AND CULT AS WAYS OF PRACTICING RELIGION IN THE PHILOSOPHY OF BERNHARD WELTE
}

\author{
AN OVERVIEW OF FUNDAMENTAL ASPECTS
}

\author{
Suzana MASLAĆ*
}

Summary: In his philosophy of religion, Welte paid particular attention to the consideration of what he called the $\gg$ practice of religion. $\ll$ Since this practice is prompted, among other things, by man's search for meaning, the article begins with Welte's exposition on the inseparable connection of meaning and religion. This, in turn, necessarily leads to the concept of God because He is the bearer of meaning. Following in the footsteps of German mysticism, and especially $M$. Eckhart, Welte refrains from subjecting God to any categoricalness and describes Him with the terms unspeakable, infinite, hidden. As one who is unspeakable and hidden, God is approached by prayer and its forms, which shows that these are the authentic ways of man's relationship toward God: thus we come to the central component of the article, which is contained in presenting the fundamental aspects of Welte's vision of prayer - prayer as silence, as speech, and as cult. Each of these approaches contains its own peculiarity: the prayer of silence is by no means a negation of true speech; the prayer of speech, on the other hand, is essentially characterized by bipolarity, while in the cult the notion of community and with it the unifying dimension of speech comes to the fore in a special way. The article concludes by considering the dangers into which the practice of religion may slip regarding prayer and cult. This perversion of religion, as the German philosopher calls it, is the old and always new problem of every religion: $\gg$ These people honor me with their lips, and their hearts are far from me.« (Mark 7:6)

Keywords: Bernhard Welte, God, religion, meaning, prayer, silence, speech, cult, perversion.

\footnotetext{
* Suzana Maslać, Mag. Theol., Catholic Faculty of Theology in Đakovo, J. J. Strossmayer University of Osijek, Petra Preradovića 17, P. O. box 54, 31400 Đakovo, Croatia, suzana.maslac@gmail.com
} 